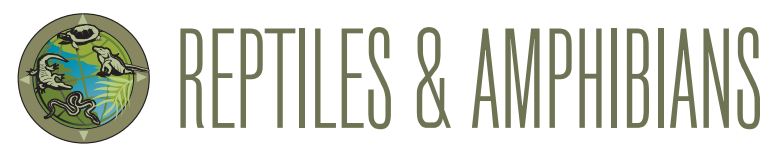

\title{
Adactyly in a Mawphlang Odorous Frog, Odorrana mawphlangensis (Pillai and Chanda 1977) (Ranidae), from Mizoram, India
}

Vanlal Siammawii, Malnica Vanlal Malsawmtluangi, Lal Muansanga, Lal Biakzuala, and Hmar Tlawmte Lalremsanga

Developmental Biology and Herpetology Laboratory, Department of Zoology, Mizoram University, Aizawl, 796004, Mizoram, India (htlrsa@yahoo.co.in)

Since Gesner (1554) reported the first case of a malforma$\checkmark$ tion in an anuran, such incidences have become alarmingly common due to overexposure to radiation and environmental contaminants (Ankley et al. 2002; Blaustein and Johnson 2003; Lunde and Johnson 2012). One type of malformation is adactyly, a specific form of ectrodactyly, which is characterized by the absence of all digits on a limb (Henle et al. 2017a).

The Mawphlang Odorous Frog, Odorrana mawphlangensis (Pillai and Chanda 1977), is a large frog distributed throughout northeastern India (Frost 2021). One population inhabiting a stream below hilly grass-covered terrain was breeding from late April and early June (Lalremsanga 2017).

An adult male $O$. mawphlangensis (SVL $78.68 \mathrm{~mm}$ ) with adactyly was collected on 11 June 2016 from a seasonal streamlet $\left(23^{\circ} 27^{\prime} 15.31 " \mathrm{~N}\right.$; $92^{\circ} 45^{\prime} 07.34^{\prime \prime} \mathrm{E} ; 1,483 \mathrm{~m}$ asl) at Hmuifang Community Reserve Forest, Aizawl District, about $50 \mathrm{~km}$ south of Aizawl, Mizoram. The specimen was identified based on the original description of the species (Pillai and Chanda 1977) and catalogued in the Departmental Museum of Zoology, Mizoram University (MZMU 132). All five digits of the left hindlimb were greatly reduced in length (Fig. 1) and we saw no evidence that this condition was a result of an injury. This is the first documented case of adactyly in this species.

Various reports revealed that exposure to water contaminated with pollutants, pesticides, herbicides, retinoids and retinoid mimics, steroid-mimicking contaminants, petrochemicals, and metals, along with microbial diseases, parasitic infections, ultraviolet radiation, and global warming are principal causes of abnormalities in anurans (see Hall and Henry 1992; Chambon 1993; Kirk 1998; Marco et al. 2002; Blaustein and Johnson 2003; Degitz et al. 2003; Ankley et al. 2002; Johnson et al. 2001; Schoff et al. 2003; Lunde and Johnson 2012; Henle et al. 2017b; Monico et al. 2019). The cause of this abnormality in this particular species and the extent of malformations among amphibians in the Hmuifang Community Reserve Forest are still unknown. Brachydactyly in a Nagaland Montane Torrent Toad (Duttaphrynus chandai) (Siammawii et al., in press) and a Tamenglong Horned

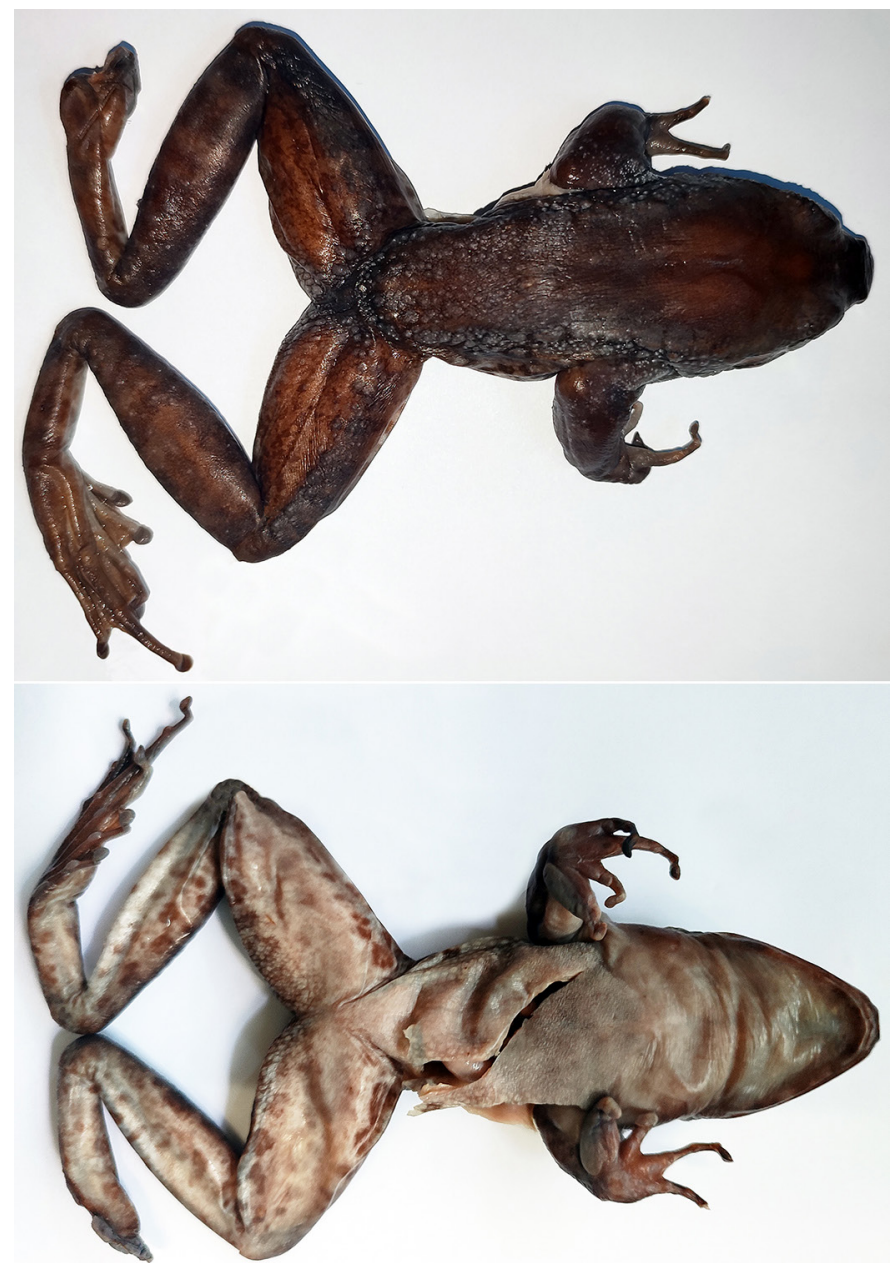

Fig. 1. Dorsal and ventral views of a Mawphlang Odorous Frog (Odorrana mawphlangensis) with adactyly on its left hindlimb. Photograph by Lal Muansanga. 
Frog (Xenophrys numbbumaeng) (Siammawii et al. 2021) have been reported from the same locality. Thus, further investigation is needed in order to identify the possible causes of this malformation.

\section{Acknowledgements}

This work was conducted under the permission for herpetofaunal collection throughout Mizoram (No.A.33011/2/99CWLW/225) issued by the Chief Wildlife Warden, Environment, Forest and Climate Change Department, Government of Mizoram, India. We acknowledge the Department of Biotechnology (DBT), Ministry of Science and Technology (No. DBT-NER/AAB/64/2017) Government of India, New Delhi, for financial support. We also express our heartfelt gratitude to Malsawmdawngliana, Ht Decemson, and M. Vabeiryureilai for their constant support in field surveys.

\section{Literature Cited}

Ankley, G.T., S.A. Diamond, and J.E. Teitge. 2002. Assessment of the risk of solar ultraviolet radiation to amphibians. I. Dose-dependent induction of hindlimb malformations in the Northern Leopard Frog (Rana pipiens). Environmental Science \& Technology 36: 2853-2858. https://doi.org/10.1021/es011195t.

Blaustein, A.R. and P.T.J. Johnson. 2003. Explaining frog deformities. Scientific American 288: 60-65. https://doi.org/10.1038/scientificamerican0203-60.

Chambon, P. 1993. The molecular and genetic dissection of the retinoid signalling pathway. Gene 135: 223-228. https://doi.org/101016/0378-1119(93)90069-f.

Degitz, S.J., G.W. Holcombe, P.A. Kosian, J.E. Tietge, E.J. Durham, and G.T. Ankley. 2013. Comparing the effects of stage and duration of retinoic acid exposure on amphibian limb development: Chronic exposure results in mortality, not limb malformations. Toxicological Sciences 74: 139-146. https://doi. org/10.1093/toxsci/kfg098.

Gesner, C. 1554. Conradi Gesneri medici Tigurini Historia Animalium Liber II. de Quadrupedibus Oviparis. Froschover, Zurich, Switzerland.

Frost, D.R. 2021. Amphibians Species of the World: An Online Reference. Version 6.1. American Museum of Natural History, New York, New York, USA. https://doi.org/10.5531/db.vz.0001. <http://amphibiansoftheworld.amnh. org/index.php>.
Hall, R.J. and P.F.P. Henry. 1992. Assessing effects of pesticides on amphibians and reptiles. Herpetological Journal 2: 65-71.

Hayes, T.B., A. Collin, M. Lee, M. Mendoza, N. Noriega, A.A. Stuart, and A. Vonk. 2002. Hermaphroditic, demasculanized frogs after exposure to the herbicide atrazine at low ecologically relevant doses. Proceedings of the National Academy of Sciences 99: 5476-5480. https://doi.org/10.1073/ pnas.082121499.

Henle, K., A. Dubois, and V. Vershinin. 2017a. Commented glossary, terminology and synonymies of anomalies in natural populations of amphibians. Mertensiella 25: 9-48.

Henle, K., A. Dubois and V. Vershinin. 2017b. A review of anomalies in natural population of amphibians and their potential causes. Mertensiella 25: 57-164.

Johnson, P.T.J., K.B. Lunde, R.W. Haight, J. Bowerman, and A.R. Blaustein. 2001. Ribeiroia ondatrae (Trematoda: Digenea) infection induces severe limb malformations in western toads (Bufo boreas). Canadian Journal of Zoology 79: 370-379. https://doi.org/10.1139/z00-210.

Kirk, J.J. 1988. Western-spotted Frog (Rana pretiosa) mortality following forests spraying of DDT. Herpetological Review 19: 51-53.

Lalremsanga, H.T. 2017. Geographic distribution. Odorrana mawphlangensis. Herpetological Review 48: 120.

Lunde, K.B. and P.T.J. Johnson. 2012. A practical guide for the study of malformed amphibians and their causes. Journal of Herpetology 46: 429-441. https://doi.org/10.2307/23327156.

Marco, A., C. Quilchano, and A.R. Blaustein. 1999. Sensitivity to nitrate and nitrite in pond-breeding amphibians from the Pacific Northwest, USA. Environmental Toxicology and Chemistry 18: 2836-2839. https://doi. org/10.1002/etc.5620181225.

Monico, A.T., T. Silva-Saores, and E.D. Koch. 2019. Malformation in three anuran species from a preserved remnant of Atlantic Forest in southeastern Brazil. Neotropical Biology and Conservation 14: 213-220. https://doi.org/10.3897/ neotropical.14.e37919.

Pillai, R.S. and S.K. Chanda. 1977. Two new species of frogs (Ranidae) from Khasi Hills, India. Journal of the Bombay Natural History Society 74: 136-140.

Schoff, P.K., C.M. Johnson, A.M. Schotthoefer, J.E. Murphy, C. Lieske, R.A. Cole, L.B. Johnson, and V.R. Beasley. 2003. Prevalence of skeletal and eye malformations in frogs from north-central United States: Estimations based on collections from randomly selected sites. Journal of Wildlife Diseases 39: 510-521. https://doi.org/10.7589/0090-3558-39.3.510.

Siammawii, V., M.V. Malwawmtluangi, L. Muansanga, L. Biakzuala, and H.T. Lalremsanga. 2021. Brachyphalangy in a Tamenglong Horned Frog, Xenophrys numbbumaeng (Mahony, Kamei, Teeling, and Biju 2020) (Megophryidae), from Mizoram, India. Reptiles \& Amphibians 28: 322-323.

Siammawii, V., L. Biakzuala, and H.T. Lalremsanga. In press. Duttaphrynus chandai. Hindlimb malformation. Herpetological Review. 